\title{
Regulation of Lipoprotein Lipase Translation by Epinephrine in 3T3-L1 Cells Importance of the 3' Untranslated Region
}

Ada Yukht, Richard C. Davis, * John M. Ong, Gouri Ranganathan, and Philip A. Kern

Department of Medicine, Division of Endocrinology, Cedars-Sinai Medical Center, Los Angeles, California 90048; and *Research, Veterans Affairs Wadsworth Medical Center, Los Angeles, California 90073

\begin{abstract}
Lipoprotein lipase (LPL) is a central enzyme in lipoprotein metabolism and is in part responsible for adipocyte lipid accumulation. Catecholamines are known to decrease the activity of LPL in adipocytes, and we have previously demonstrated that this inhibition occurs posttranscriptionally, with a prominent inhibition of LPL translation. To better characterize the inhibition of LPL translation, 3T3-L1 cells were differentiated into adipocytes, and exposed to epinephrine. Epinephrine induced a dose-dependent decrease in LPL synthesis using $\left[{ }^{35} \mathrm{~S}\right]$ methionine incorporation, with no change in LPL mRNA levels, demonstrating translational regulation of LPL in this cell line. The poly A-enriched RNA from epinephrine-treated cells was translated well in vitro, and there was no difference in the polysome profiles from control and epinephrine-treated cells, suggesting that epinephrine did not affect mRNA editing, and did not induce an inhibition of translation initiation. To obtain evidence for the presence of an inhibitory factor, a cytoplasmic extract from control, and epinephrine-treated adipocytes was human. When compared to the control cell extract, the epinephrine-treated cell extract sharply inhibited LPL translation in vitro, yet had no effect on the translation of other mRNAs. Epinephrine-treated cells had fourfold more of this inhibitor activity than control cells, and this translation inhibition was partially reversed by heat treatment. To determine what region of the LPL mRNA was involved in the translation inhibition, different $L P L$ constructs were synthesized. The inhibitory effect of the epinephrine-treated cell extract was dependent on the presence of the first 40 nucleotides of the $3^{\prime}$ (untranslated region UTR) (nucleotides 1599-1638), whereas deletion of the $5^{\prime}$ UTR and other areas of the $3^{\prime}$ UTR had no effect on translation inhibition. When a sense RNA strand corresponding to this region was added to the in vitro translation reaction, it restored translation towards normal, suggesting that the sense strand was competing for a transacting binding protein.

Thus, epinephrine-treated adipocytes produced a transacting factor, probably a protein, that interacted with a region on the LPL mRNA between nucleotides 1599 and 1638, resulting in an inhibition of translation. These studies add new insight into the hormonal regulation of LPL. ( $J$.
\end{abstract}

Address correspondence to Philip A. Kern, ACOS-Research, Veterans Affairs Medical Center, 4300 W. 7th Street, Little Rock, AR 72205. Phone: 501-660-2035; FAX: 501-671-2510.

Received for publication 17 May 1995 and accepted in revised form 20 July 1995.

The Journal of Clinical Investigation, Inc

Volume 96, November 1995, 2438-2444
Clin. Invest. 1995. 96:2438-2444.) Key words: gene expression • translation • messenger RNA • catecholamines

\section{Introduction}

Lipoprotein lipase (LPL) ${ }^{1}$ is a central enzyme in lipid metabolism and is subject to regulation by many different hormones and physiologic conditions ( 1 ). In adipocytes, LPL is increased in the fed state, and is stimulated by insulin in vitro, whereas hormones that are elevated during the fasting state, such as epinephrine and glucagon, inhibit LPL.

Although the changes in LPL activity with different physiologic states have been well described, more recent studies have suggested that the mechanism of LPL regulation is complex. Depending on the regulator or the cell type, LPL regulation may be due to changes at the mRNA level, or at numerous posttranscriptional sites (reviewed in reference 1). For example, the addition of insulin to primary cultures of rat adipocytes led to an increase in LPL expression through an increase in LPL mRNA levels $(2,3)$. However, fed rats and humans demonstrated an increase in LPL activity through posttranslational mechanisms $(4,5)$.

We and others have recently described several instances of regulation of LPL translation. In response to glucose (6), thyroid hormone (7), and catecholamines (8), there were large changes in LPL synthesis, using $\left[{ }^{35} \mathrm{~S}\right]$ methionine pulse labeling, in spite of no changes in adipocyte LPL mRNA levels. In the case of catecholamines, there was a large and rapid decrease in LPL synthesis within $30 \mathrm{~min}$ of the addition of epinephrine to rat adipocytes, with no change in LPL mRNA (8). However, the mechanism of this translational regulation has not been described.

The regulation of translation has been well characterized in other systems (9). The iron-binding protein ferritin is regulated at the level of initiation by a transacting protein that binds to a region of secondary structure on the $5^{\prime}$ untranslated region (UTR) of the ferritin mRNA (10-12). On the other hand, other studies have implicated changes in the $3^{\prime}$ UTR of mRNA in the regulation of translation (13). The $3^{\prime}$ UTR is involved in the inhibition of translation of $\gamma$-interferon in Xenopus oocytes (14), and creatine kinase in the U937 cell line (15). Studies with ornithine decarboxylase, which is under translational control by polyamines, have demonstrated coordinated regulation of translation by both the $5^{\prime}$ and 3' UTR's $(16,17)$.

This study was intended to better characterize the translational regulation of LPL by epinephrine. As described below, we provide evidence for the interaction of a cytoplasmic factor

1. Abbreviations used in this paper: HSL, hormone-sensitive lipase; LPL, lipoprotein lipase; Neo, neomycin phosphotransferase; RT, reverse transcriptase; UTR, untranslated region. 
with the 3' end of the LPL mRNA, which resulted in an inhibition of LPL translation.

\section{Methods}

Cell culture and differentiation. Mouse fibroblast 3T3-L1 cells were grown on $75-\mathrm{cm}^{2}$ culture flask (Costar Corp., Cambridge, MA), in DME (GIBCO BRL, Rockville, MD), supplemented with $10 \%$ fetal calf serum. Cells were grown to confluence and differentiated by incubation in DME with $10 \%$ fetal calf serum containing $1 \mu \mathrm{g} / \mathrm{ml}$ insulin, 0.5 $\mathrm{mM}$ isobutylmethylxanthine, and $0.25 \mu \mathrm{M}$ dexamethasone for $72 \mathrm{~h}$. Cells were then maintained in DME containing $10 \%$ serum and $1 \mu \mathrm{g} /$ $\mathrm{ml}$ insulin for 5-7 d. Medium was then changed to DME containing $10 \%$ serum.

LPL synthetic rate. LPL synthetic rate was measured in cultured cells as described previously (2). Cells were incubated in methioninefree medium for $2 \mathrm{~h}$ before the addition of $50 \mu \mathrm{Ci}\left[{ }^{35} \mathrm{~S}\right]$ methionine for $30 \mathrm{~min}$. The cells were lysed and immunoprecipitated with anti-LPL antibodies (18), followed by analysis of the samples on a $10 \%$ polyacrylamide-SDS gel, followed by autoradiography. Within each experiment, an aliquot of cell lysate was precipitated with TCA and counted and the amount of lysate taken for immunoprecipitation was adjusted to give equal TCA counts.

RNA extraction and Northern blotting. RNA was extracted from 3T3-L1 cells by adding RNA extraction buffer ( $4 \mathrm{M}$ guanidinium thiocyanate, $0.5 \%$ SDS, $0.1 \mathrm{M} \beta$-mercaptoethanol, and $25 \mathrm{mM}$ Na citrate, $\mathrm{pH} 7.0$ ) and scraping with a rubber policeman. RNA extraction used the methods of Chomczynzki and Sacchi (19), and RNA was quantitated spectrophotometrically, and the quality of RNA was verified by ethidium bromide staining of rRNA bands on a minigel. Equal amounts of total RNA were resolved on a 2.2-M formaldehyde-1\% agarose gel, transferred to a nylon membrane (Hybond-N; Amersham Corp., Arlington Heights, IL), and blotted with the ${ }^{32} \mathrm{P}$-labeled (20) cDNA probes for human LPL (21), and $\gamma$-actin (22), as described previously (8).

Preparation of cytoplasmic cell extract. A cytosolic fraction was prepared as a modification of a method previously described (23). Control and epinephrine-treated 3T3-L1 adipocytes were homogenized in 2 vol of lysis buffer ( $50 \mathrm{mM}$ Tris- $\mathrm{HCl}, \mathrm{Ph} 7.4,250 \mathrm{mM}$ sucrose, 35 $\mathrm{mM} \mathrm{KCl}, 10 \mathrm{mM} \mathrm{MgCl}_{2}, 0.5 \mathrm{mM}$ EDTA, $7 \mathrm{mM} \beta$-mercaptoethanol), using 10 strokes of a glass homogenizer. Homogenates were centrifuged at $10,000 \mathrm{~g}$ for $15 \mathrm{~min}$ at $4^{\circ} \mathrm{C} .5 \mathrm{ml}$ of the postnuclear extract was used to prepare a high speed supernatant fraction ( $S-100)$ by centrifugation at $100,000 \mathrm{~g}$ for $2 \mathrm{~h}$ at $4^{\circ} \mathrm{C}$. Solid ammonium sulfate was added to the cytosolic fraction to $60 \%$ saturation and precipitated for $1 / 2 \mathrm{~h}$ on ice. Precipitated proteins were collected by centrifugation at $6,000 \mathrm{~g}$ for 10 min at $0^{\circ} \mathrm{C}$, redissolved and dialyzed against buffer A $(20 \mathrm{mM}$ Tris$\mathrm{HCl}, \mathrm{pH} 7.4,20 \mathrm{mM} \mathrm{KCl}, 7 \mathrm{mM} \beta$-mercaptoethanol, $0.1 \mathrm{mM}$ EDTA, and $10 \%$ glycerol). Protein concentration in the cell extract was determined with a protein assay (BioRad Laboratories, Richmond, CA), using BSA as a standard. Equal quantities of the cell extract $(0.1 \mu \mathrm{g})$ were used in the rabbit reticulocyte lysate.

In vitro translation. For in vitro translation, RNA transcripts from a variety of human LPL cDNA constructs were used (described below). In addition, RNA transcripts were made from the cDNA's for human hormone-sensitive lipase (HSL) (24), human colipase (25), and neomycin phosphotransferase (Neo) (26). Template DNA was linearized with a suitable restriction enzyme to obtain a complete transcript of the cloned DNA. $1 \mu \mathrm{g}$ of linearized DNA was transcribed with either SP6 or T7 Polymerase using SP6/T7 Transcription Kit (Boehringer Mannheim Biochemicals, Indianopolis, IN). Equal quantities of RNA transcripts $(0.1 \mu \mathrm{g}$ ) were translated in a rabbit reticulocyte lysate system (Promega Corp., Madison, WI) in the presence of $\left[{ }^{35} \mathrm{~S}\right]$ methionine, and the translation products were analyzed by SDS-PAGE and autoradiography. For in vitro translation of poly A-enriched RNA, total RNA was extracted from control and epinephrine-treated 3T3-L1 cells. Poly A-enriched RNA was prepared using the poly A tract mRNA isolation system III (Promega Corp). Equal quantities ( $1 \mu \mathrm{g}$ ) of RNA were added to the rabbit reticulocyte lysate system in the presence of $\left[{ }^{35} \mathrm{~S}\right]$ methionine. Translation products were immunoprecipitated and proteins were analyzed by SDS-PAGE and autoradiography.

Polysome preparation and reverse transcriptase PCR (RT-PCR). Polysome profiles were obtained essentially as described previously (27). Control and epinephrine-treated 3T3-L1 adipocytes were washed and then homogenized in 2 vol of buffer I ( $10 \mathrm{mM}$ Tris- $\mathrm{HCl} \mathrm{pH} \mathrm{7.4,}$ $10 \mathrm{mM} \mathrm{KCl}, 5 \mathrm{mM} \mathrm{MgCl}$, $20 \mathrm{U} / \mathrm{ml}$ Rnasin, $2.75 \mathrm{mM}$ dithiothreitol, $0.1 \%$ Triton X-100,150 $\mu \mathrm{g} / \mathrm{ml}$ cycloheximide, $250 \mu \mathrm{g} / \mathrm{ml}$ Heparin), in a glass homogenizer by 10 strokes on ice. Mitochondria and nuclei were pelleted at $10,000 \mathrm{~g}$ for $10 \mathrm{~min}$, and the postmitochondrial supernatant, reconstituted with $0.25 \mathrm{M}$ sucrose and $0.1 \mathrm{M} \mathrm{KCl}$, was layered over 10-50\% sucrose gradients prepared with buffer II ( $20 \mathrm{mM}$ Hepes, $\mathrm{pH}$ $7.2,0.25 \mathrm{M} \mathrm{KCl}, 10 \mathrm{mM} \mathrm{MgCl}, 20 \mathrm{mM}$ dithiothreitol, $150 \mathrm{mg} / \mathrm{ml}$ cycloheximide, $100 \mathrm{U} / \mathrm{ml}$ Rnasin, and $0.5 \mu \mathrm{g} / \mathrm{ml}$ heparin). Gradients were centrifuged at $180,000 \mathrm{~g}$ for $3 \mathrm{~h}$ at $4^{\circ} \mathrm{C}$. To demonstrate the release of all LPL mRNA into the free fraction, $1 \mathrm{mM}$ EDTA was added to a control gradient. Gradients were collected in $121-\mathrm{ml}$ fractions, and polysome profiles were recorded by reading UV absorption at $260 \mathrm{~nm}$. Each fraction was precipitated and RNA was extracted. Measurement of LPL mRNA levels in each fraction was done using RT-PCR, as described previously (28). The primers for this reaction were derived from the mouse LPL cDNA sequence, and the upstream primer was nucleotides 1158-1177, and the downstream primer was nucleotides 1369-1389 (29). An equal volume of each fraction (containing 0.1 1.0 ng RNA) was reverse transcribed, followed by PCR for 35 cycles at $55^{\circ} \mathrm{C}$. The resulting ethidium bromide-stained gel was imaged using an Imagestore 5000 scanner, and analyzed using the Gelbase/Gelblot software (Ultraviolet Products, Ltd., San Gabriel, CA).

Preparation of constructs. Clone B (see Fig. 6) is LPL35, described by Wion et al. (21). It contained 174 nucleotides of $5^{\prime}$ untranslated sequence, the complete coding, sequence (1428 nucleotides) and 822 nucleotides of the 1950-nucleotide 3' UTR.

The full length 3.6-kb LPL construct (see clone A in Fig. 6) was prepared using overlapping clones of human LPL cDNA in pGEM4Z (21), as described previously (30). For clone C, LPL35 (clone B) was cut at the EcoRI site at nucleotide 1638 . For clone D, the entire $5^{\prime}$ UTR of LPL35 was replaced with six nucleotides encoding a BamHI site, and all but 44 nucleotides of the $3^{\prime}$ UTR was removed. This was accomplished using PCR to amplify the appropriate region of LPL35. The upstream primer (TGAC GGATCC ATG GAG AGC AAA GCC CTG CTC) consisted of four flanking nucleotides, a BamHI site, and the first 21 nucleotides of the coding region. The downstream primer (ACGT GGATCC GAA TTC ACA TGC CGT TCT TTG) consisted of four flanking nucleotides, a BamHI site and reverse compliment for 21 nucleotides of the cDNA ending at the EcoRI site at nucleotide 1638 . To minimize nucleotide misincorporation, amplification was carried out using VENT (New England Biolabs, Beverly MA) polymerase with proof-reading activity. The resulting fragment was cloned into pGEM2 using the BamHI and EcoRI sites.

Clone E was a generous gift of Dr. Robert H. Eckel (University of Colorado School of Medicine). The human LPL cDNA (clone B, see above) was used as a template for PCR and the introduction of convenient restriction sites (EcoR1 and HindIII) and the elimination of the 5' and 3' UTR's. PCR was performed using as upstream and downstream primers CTTAAGCTTCCCGA GATGGAGAGC and ATGAGAATT CAGCCTG ACTTCTT, respectively. The resulting sequence was cloned into pGEM2 for in vitro transcription.

Clones $\mathrm{F}$ and $\mathrm{G}$ contained shortened coding sequences created by using PCR to insert a stop codon after codons 302 and 322, respectively. The upstream primer (GACT GAATTC GCCACC ATG GAG AGC AAA GCC CTG CTC) contained four flanking nucleotides, an EcoRI site, six nucleotides representing consensus Kozak sequence for translation initiation, and the first 21 nucleotides of coding sequence. The downstream primers for clone F (ACGT GGATCC TCA AAA ATG AAT CTT TAC TTG GTA) and clone G (ACGT GGATCC TCA GTA CAT TTT GCT GCT TCT TT) contained four flanking nucleotides, a BamHI site, and reverse complement for a stop codon and 20 to 21 


\section{EFFECT OF EPINEPHRINE ON LPL TRANSLATION IN 3T3-L1 CELLS}

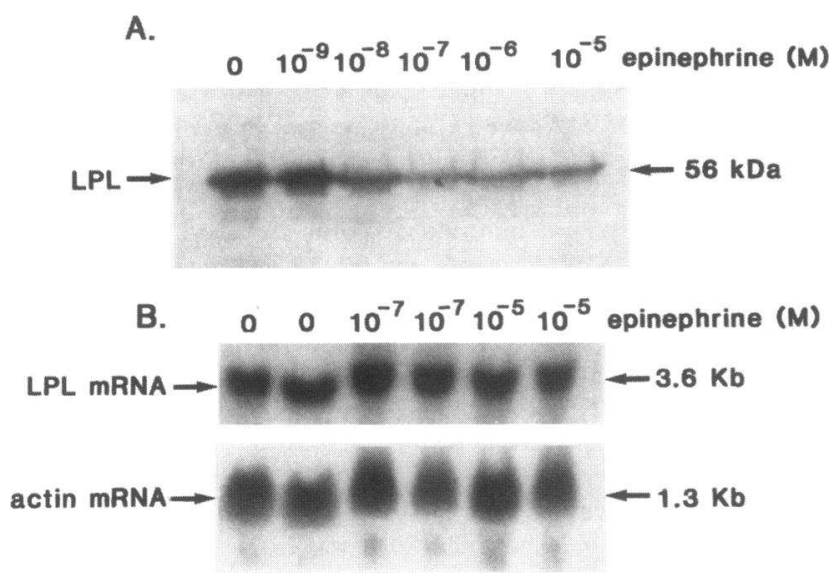

Figure 1. Effect of epinephrine on LPL synthesis in 3T3-L1 cells. Cells were differentiated as described in Methods, and epinephrine was then added in increasing quantities for $2 \mathrm{~h}$. $(A)$ Cells were pulse-labeled with $\left[{ }^{35} \mathrm{~S}\right]$ methionine and immunoprecipitated. $(B)$ Northern blot of cells treated with epinephrine. The data are one of three representative experiments.

nucleotides of coding sequence preceding codons 323 and 303, respectively. After PCR using the proofreading polymerase, the fragments was cloned into the EcoRI and BamHI sites of pGEM2.

The sense RNA strand (see Fig. 7) was generated by PCR of the clone B, using the appropriate primers, except for the addition of $\mathrm{T} 7$ polymerase sequences on the upstream primer.

For expression, purified plasmid DNA was digested at a polylinker restriction site downstream of the LPL insert, and in vitro RNA transcription was carried out using the appropriate upstream promoter for viral RNA polymerase.

\section{Results}

In a previous study $(8)$, we determined that LPL was regulated by epinephrine at the translational level in rat adipocytes. To determine whether 3T3-L1 cells responded similarly, 3T3-L1 cells were induced to differentiate, as described in Methods, and then exposed to increasing concentrations of epinephrine $\left(10^{-9}\right.$ to $\left.10^{-5} \mathrm{M}\right)$. After a 2-h exposure to epinephrine, cells were pulse-labeled with $\left[{ }^{35} \mathrm{~S}\right]$ methionine for $30 \mathrm{~min}$, followed by immunoprecipitation of LPL. As shown in Fig. $1 A$, the addition of epinephrine resulted in a dose-dependent decrease in immunoprecipitable radiolabeled LPL, such that there was minimal radiolabeled LPL after exposure to $10^{-5} \mathrm{M}$ epinephrine. To determine whether the decrease in LPL synthesis was paralleled by a decrease in LPL mRNA levels, cells were treated with epinephrine, followed by RNA extraction and Northern analysis. As shown in Fig. $1 B$, addition of the same concentrations of epinephrine for $2 \mathrm{~h}$ had no effect on LPL mRNA levels, compared to the message for $\gamma$-actin. Thus, the decrease in LPL synthesis, without a comparable decrease in mRNA level, suggested translational control.

Previous studies have described the regulation of translation of ferritin due to the binding of a transacting protein to the $5^{\prime}$ UTR, resulting in dissociation of the ferritin mRNA from polysomes (10). To determine whether epinephrine caused LPL

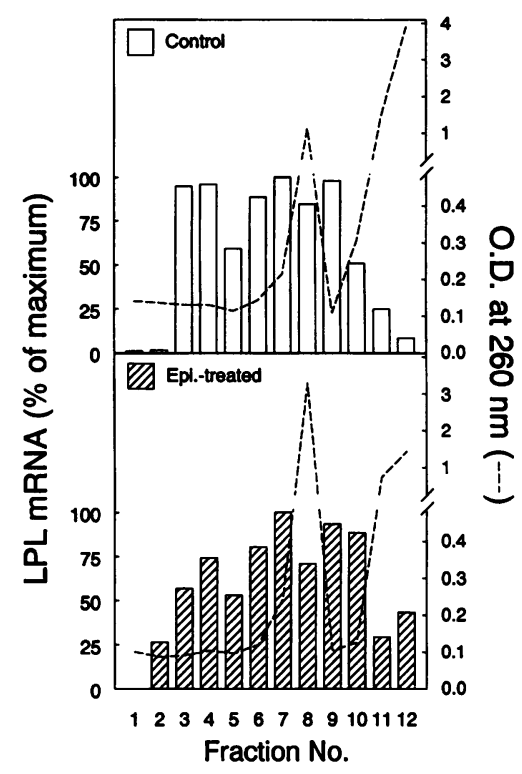

Figure 2. Effect of epinephrine treatment of LPL mRNA distribution in polysomes. Total RNA was extracted from control cells, and cells treated with $10^{-5} \mathrm{M}$ epinephrine, followed by centrifugation through a $10-50 \%$ sucrose gradient, as described in Methods, to separate free mRNA from monosomeand polysome-associated mRNA. Fractions were numbered 1 through 12 , referring to the bottom to the top of the gradient, respectively. Ethidium bromide staining of each fraction was performed to identify the ribosomal RNA ( 18 S and 28S) sub-

units. Fractions 11-12 contained individual ribosomal subunits, and fractions $1-10$ contained both $18 \mathrm{~S}$ and $28 \mathrm{~S}$ ribosomal subunits, indicating polysomes and monosomes. The main UV absorbance peak was in fraction 8, which corresponded with monosomes or short polysomes. The amount of LPL mRNA present in each fraction was quantitated using RT-PCR, and expressed as a percentage of maximum LPL mRNA. The data shown are the mean values from two experiments.

mRNA to become less associated with polysomes, and therefore less efficiently translated, we examined the distribution of LPL mRNA in polysomes of 3T3-L1 adipocytes that had been treated with epinephrine for $2 \mathrm{~h}$. A postmitochondrial supernatant was prepared from control and epinephrine-treated 3T3-L1 adipocytes, as described in Methods. This fraction, which contained polysomes, monosomes, free ribosomes, as well as nonribosome-associated RNA, was layered onto a $10-50 \%$ sucrose gradient, followed by ultracentrifugation. Fractions were collected and the LPL mRNA quantitated in each fraction using RT-PCR. As shown in Fig. 2, the LPL mRNA was distributed throughout a broad range of ribosomal units. However, in cells that had been translationally repressed from prior exposure to epinephrine, there was no change in the polysome profile. In particular, there was no shift of the LPL mRNA from the denser polysome fractions to the lighter monosome or free mRNA fractions, as one would predict with a dissociation from polysomes due to an inhibition of initialization.

Regulation could have been due to mRNA editing or some other structural alteration in the LPL mRNA. To determine whether epinephrine treatment of the cells rendered the LPL mRNA untranslatable, poly A-enriched RNA was prepared from control and epinephrine-treated cells. Equal quantities (1 $\mu \mathrm{g})$ of RNA were added to the translation system for $60 \mathrm{~min}$ in the presence of $\left[{ }^{35} \mathrm{~S}\right]$ methionine, followed by immunoprecipitation with anti-LPL antibodies. As shown in Fig. 3, the poly A-enriched RNA from both control and epinephrine-treated cells translated equally in vitro, indicating that structural changes in LPL mRNA were not a factor in controlling translation.

Another possible mechanism for translational regulation of LPL could involve the production of a transacting substance 


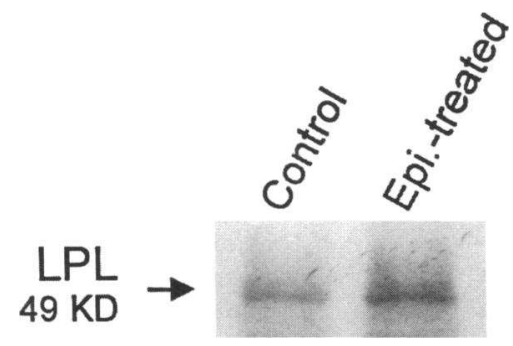

Figure 3. Translatability of LPL mRNA after epinephrine. Poly A-enriched RNA was extracted from control, and epinephrine-treated cells, as described in Methods. Equal quantities $(1 \mu \mathrm{g})$ of RNA were added to the reticulocyte lysate system, followed by immunoprecipitation with anti-LPL antibodies. Shown is one of two representative experiments.

that bound to the LPL mRNA, resulting in inhibition of translation. To determine whether such a substance was present, a cytoplasmic extract was prepared from control and epinephrinetreated cells, as described in Methods, and added to the in vitro translation system. Equal quantities ( $0.1 \mu \mathrm{g}$ of protein) of the cytosolic fractions from control and epinephrine-treated cells were added to the rabbit reticulocyte lysate system, followed by the addition of an in vitro transcribed LPL mRNA (3.6 $\mathrm{kb}$ ), and $\left[{ }^{35} \mathrm{~S}\right]$ methionine. As shown in Fig. 4, the epinephrinetreated cell extract had a greater inhibitory effect on LPL translation, when compared to the control cell extract. These inhibitory properties were partially eliminated when the epinephrinetreated cell extract was heated to $95^{\circ} \mathrm{C}$ for $5 \mathrm{~min}$. In the absence of any cell extract, translation of LPL was slightly higher than in the presence of the control extract. To determine whether this extract had nonspecific inhibitory properties on translation, a number of controls were performed. There was no change in the translation of HSL and Neo when control and epinephrinetreated cell extract was added to the in vitro translation system (Fig. 4). In addition, the translation of human colipase was not affected by the epinephrine cell extract (data not shown). These data demonstrated that a factor in the epinephrine-treated cell extract inhibited translation of LPL mRNA, and had no effect on the translation of other mRNA's.

Some inhibition of LPL translation was apparent when control cell extract was added to the in vitro translation system. To determine the magnitude of the inhibitory effect of the epineph-

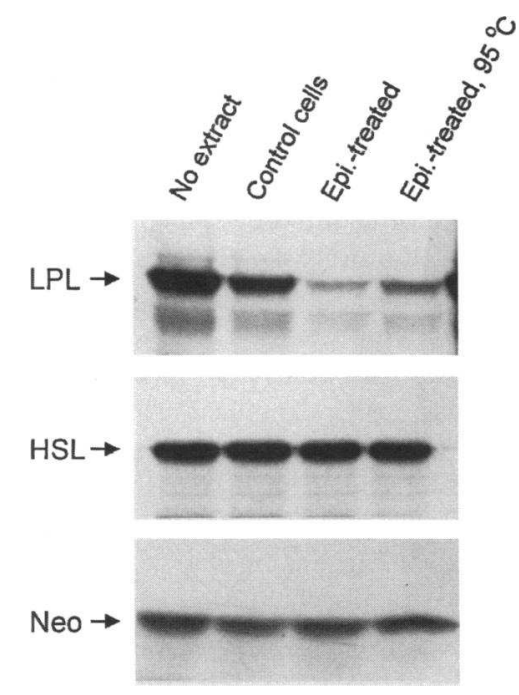

Figure 4. Effects of a cytoplasmic extract on LPL translation. A cytosolic (S-100) fraction was prepared from control, and epinephrine-treated 3T3- $\mathrm{L} 1$ adipocytes, as described in Methods.

This cytoplasmic extract was added to an in vitro translation, consisting of rabbit reticulocytes, $\left[{ }^{35} \mathrm{~S}\right]$ methionine, and one of the following in vitro transcribed mRNAs: human LPL (full-length $3.6 \mathrm{~kb}$ ), human HSL, and Neo. Translation was performed for $60 \mathrm{~min}$, and

the translation products were analyzed by SDS-PAGE and autoradiography. The data shown are representative of five experiments.

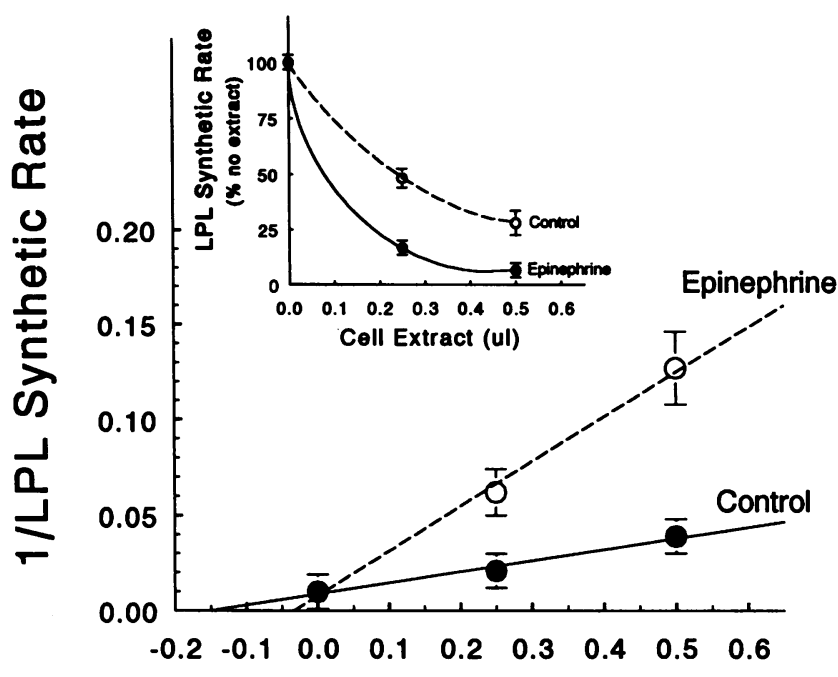

\section{Cell Extract (ul)}

Figure 5. Relative inhibition of in vitro translation between control and epinephrine-treated cell extracts. Cytosolic cell extracts were prepared from control and epinephrine-treated cells and diluted in buffer A (see Methods), and added to the in vitro translation reaction. Data are expressed in relation to the addition of no cell extract. Using a Dixon plot, the quantity of cell extract yielding half-maximal synthetic rate was $0.19 \mu \mathrm{l}$ for control cells and $0.05 \mu \mathrm{l}$ for epinephrine-treated cells. (Inset) Inhibition of LPL in vitro translation by the control and epinephrine extracts.

rine-treated cell extract in relation to the control extract, different amounts of cell extracts were added to the in vitro translation system. As shown in Fig. 5, the addition of increasing amounts of cell extract resulted in increased inhibition of LPL translation. When a Dixon plot was performed with these data (Fig. 5), the concentrations of cell extract that yielded half-maximal LPL synthetic rates were determined. These data demonstrated that the inhibitory activity in the epinephrine cell extract was fourfold higher when compared to the control cells.

To determine what region of the LPL mRNA was involved in translational regulation, a series of LPL constructs were used in the in vitro translation system, as shown in Fig. $6 \mathrm{~A}$. In addition to the use of the full-length 3.6-kb LPL mRNA (construct A), other constructs contained progressive deletions of the $3^{\prime}$ UTR, along with deletions of the 5' UTR. Of note, constructs C and D contained identical $3^{\prime}$ UTR deletions (at nucleotide 1638 ), but construct $\mathrm{D}$ also contained a truncated 5' UTR. Constructs F and G contained a truncated LPL coding sequence, along with a truncated $5^{\prime}$ UTR.

Each of the constructs shown in Fig. $6 \mathrm{~A}$ were transcribed, and added to the reticulocyte lysate system in the presence of either the control or epinephrine-treated cell extracts. As shown in Fig. $6 B$, constructs $A, B, C$, and D all translated well, and responded similarly to the cell extracts: a greater inhibition of translation by the epinephrine-treated cell extract, when compared to the control cell extract. However, constructs E, F, and G, which contained a deletion of all of the 3' UTR, all of the $5^{\prime}$ UTR, and some of the COOH-terminal end of the coding sequence, translated well, but were not affected by the epinephrine-treated cell extract. This lack of response to the epinephrine-treated cell extracts appeared to be due to the sequence 
A

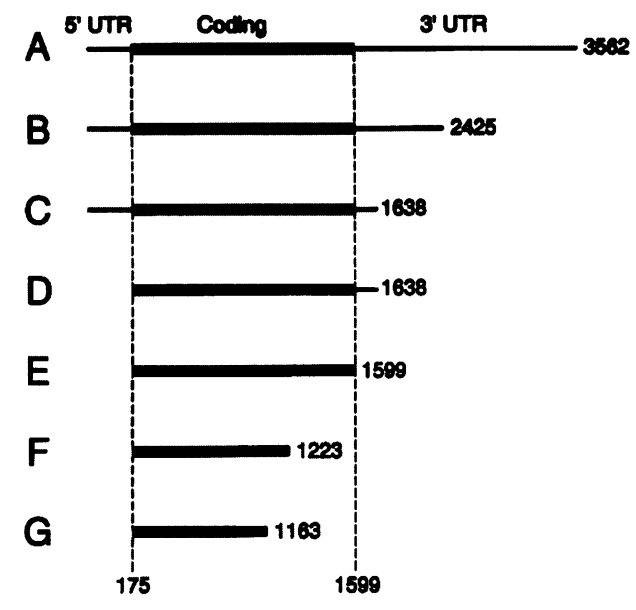

B

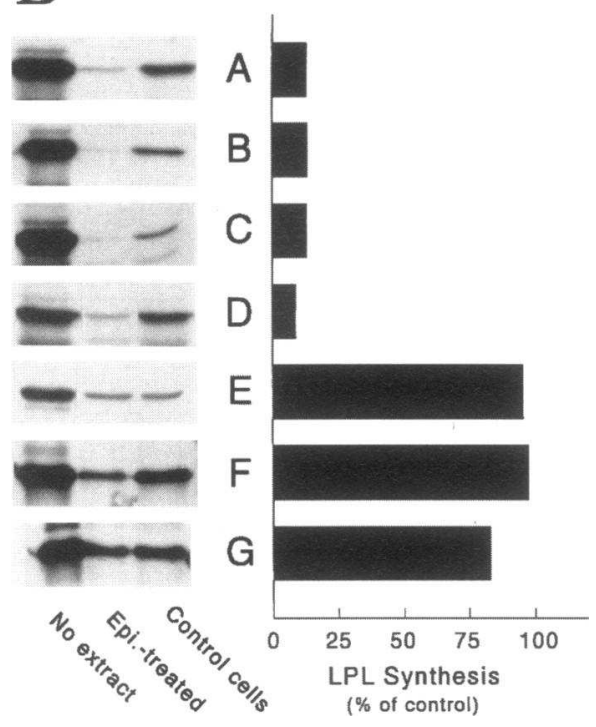

Figure 6. (A) LPL constructs used for analysis of translational regulation in response to epinephrinetreated cell extracts. The generation of these constructs is described in Methods. ( $B$ ) Effect of the cytoplasmic extracts in the different LPL constructs. Cytoplasmic extracts derived from control, and epinephrine-treated cells were added to reticulocytes in the presence of each of the constructs in $A$. Autoradiograms are from representative experiments, and at least three experiments were performed with each construct. The bar graph for each construct represents the mean of the densitometric images, expressed as a percentage of the image obtained from the control cell extract. between nucleotide 1599 and 1638 in the $3^{\prime}$ UTR. The 5' UTR of the LPL mRNA was not involved in the response to the epinephrine-treated cell extract, since constructs $C$ and $D$ both responded similarly, even though construct $\mathrm{D}$ contained a truncated 5' UTR.

The inhibition of LPL synthesis by the epinephrine-treated cell extract could be due to the production of a binding protein that bound to the 3' UTR. If so, the addition of a sense RNA strand would be expected to compete for this binding protein, and remove the translation inhibition. Thus, a sense RNA strand was transcribed and added to the epinephrine-treated cell extract before the addition of the complex to the in vitro translation system. As shown in Fig. 7 (top), this 628-bp sense strand contained the sequences from nucleotides 1512 to 2140 , which covered the last 87 nucleotides of the coding sequence, and the first 541 nucleotides of the 3' UTR. Translation in the absence of competitor RNA (Fig. 7, None) was decreased in the presence of the epinephrine-treated cell extract. With the addition of

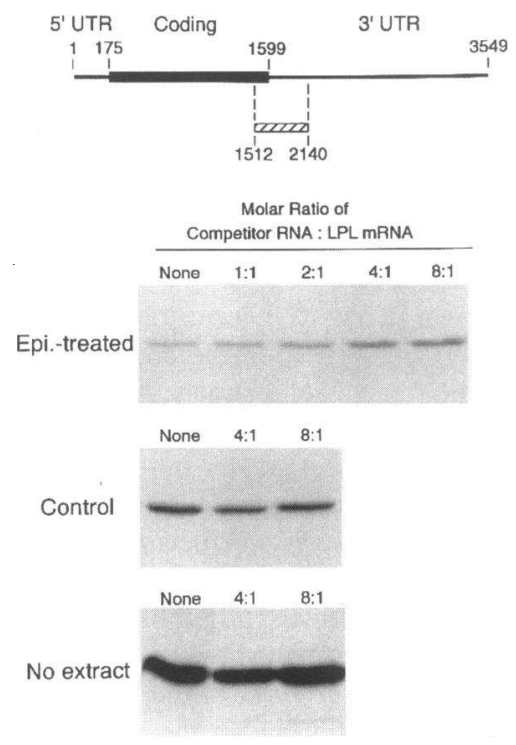
with sense RNA strand. An RNA sense strand corresponding to nucleotides $1512-2140$ was synthesized as described in Methods and added to the in vitro translation system along with cell extracts from control and epinephrine-treated cells. Increasing quantities of sense RNA were added, up to a sense RNA were added, up to a sense RNA/LPL mRNA molar ratio of $8: 1 .\left[{ }^{35} \mathrm{~S}\right]$ methionine was then added, and in vitro trans$60 \mathrm{~min}$.
Figure 7. Competition lation then proceeded for increasing amounts of competitor RNA to the in vitro translation reaction, there was a progressive increase in LPL translation; i.e., a diminished effect of the epinephrine-treated cell extract. On the other hand, the competitor RNA fragment had no effect on the control cell extract, and had no effect on the in vitro translation reaction in the absence of any cell extract. Furthermore, the addition of a similar sized sequence of irrelevant mRNA (Neo) had no effect on the epinephrine cell extract (data not shown). Thus, the sense RNA strand appeared to compete with the LPL mRNA for an inhibitory binding factor.

\section{Discussion}

Previous studies of LPL have demonstrated that regulation occurs at numerous posttranscriptional sites. Depending on the cell type or regulatory factor, changes in LPL may be due to changes in mRNA levels $(2,31-34)$, changes in translation $(6-8,35,36)$, or changes in posttranslational processing $(4$, $5,37,38)$. Catecholamines have long been known to inhibit the activity of LPL, and this inhibition is of physiologic importance in the mobilization of adipose tissue lipid during fasting, and in response to exercise $(39,40)$. In a previous study, we examined the regulation of LPL by catecholamines in primary cultures of rat adipocytes (8). LPL synthetic rate was inhibited more than fivefold within 30 min of addition of epinephrine to the medium, with no change in LPL mRNA levels. This inhibition of LPL synthesis occurred at low concentrations of epinephrine ( $1 \mathrm{nM})$, but further inhibition of LPL synthesis occurred at higher concentrations. In this study, the mechanism of this translational inhibition was further examined using 3T3L1 adipocytes.

As with rat adipocytes, 3T3-L1 cells demonstrated translational regulation, as manifested by an inhibition of LPL synthesis using $\left[{ }^{35} S\right]$ methionine pulse labeling, and no change in LPL mRNA levels. A number of possible mechanisms for translational regulation were examined. Changes in mRNA structure could have occurred, perhaps due to mRNA editing (41), which could make the mRNA untranslatable. To determine whether such changes were present, poly A-enriched RNA from control 
and translationally repressed (epinephrine-treated) cells were translated in vitro in reticulocyte lysates. No change in in vitro translation was observed, demonstrating that there was no loss of translatability of the LPL mRNA. Because RNA binding proteins would be lost in the process of isolation of poly $\mathrm{A}$ enriched RNA, these data do not rule out the presence of a transacting RNA-binding protein.

Translation may be regulated at the level of initiation, as illustrated by the iron-binding protein ferritin (10). The 5' UTR of the ferritin mRNA contains a stem-loop structure, which is the binding site for a protein that inhibits mRNA initiation by dissociating ferritin mRNA from polysomes. To determine whether epinephrine treatment of adipocytes resulted in a dissociation of the LPL mRNA from ribosomes, polysome profiles of LPL were analyzed from control and epinephrine-treated adipocytes. No shift in polysome profile was observed in the epinephrine-treated cells, suggesting that the inhibition of translation was not due to an inhibition of initiation.

To obtain evidence for the presence of a transacting factor that regulated translation, a cytosolic fraction was prepared from control and translationally repressed cells. When this cytosolic fraction was added to an in vitro translation system, containing the full-length human LPL mRNA (transcribed in vitro from the 3.6-kb LPL cDNA), the addition of the cytosolic fraction from the translationally repressed cells resulted in an inhibition of LPL synthesis. This cell extract was specific for LPL, and had no effect on other mRNAs. The control cytosolic fraction also inhibited translation, when compared to the addition of no cell extract, and the examination of the control and epinephrinetreated cell extracts relative translation inhibition suggested that the inhibitory factor was present in both control and epinephrine-treated cell extracts, but was about fourfold higher in the epinephrine cell fraction. This factor was likely a protein, since it was partially inhibited by heat treatment. Although it is possible that the inhibitory factor was an RNA, there is no precedent for naturally occurring regulatory RNAs in eukaryotes (9).

To determine what region of the LPL mRNA was involved in translational regulation, a series of LPL cDNA constructs were produced, transcribed into RNA, and translated in the reticulocyte lysate system in the presence and absence of the same cytosolic fractions. Constructs with truncation of the 5' UTR translated well in vitro, and were inhibited by the addition of the epinephrine-treated cell cytosolic fraction, as long as there was some 3' UTR present. From these constructs, the first 39 nucleotides of the $3^{\prime}$ UTR (nucleotides 1599-1638) was the region of importance for LPL translation inhibition by epinephrine. To confirm that this region was important, and to obtain evidence for the presence of a binding protein, an RNA sense strand from this region was added to the in vitro translation reaction. This sense strand prevented the translation inhibition by the epinephrine-treated cell extract, indicating competition for an inhibitory factor.

Numerous studies have demonstrated the importance of the 3' UTR in mRNA stability, and several studies have shown that the 3' UTR can control translational efficiency as well (9, 42 ). The $\beta$-interferon mRNA is translated very inefficiently in Xenopus oocytes, and the inhibitory effect lies mainly with the $3^{\prime}$ UTR, although the coding sequence of $\beta$-interferon also contributes, since the substitution of another protein's coding sequence partially overcomes the translation inhibition (14). Creatine kinase translation is also regulated by the $3^{\prime}$ UTR through a mechanism that does not involve translation initiation.
Studies in the U937 cell line showed that an inhibition of translation elongation or termination was due to a soluble cytoplasmic factor(s), probably a protein, that bound to a region of the $3^{\prime}$ UTR near the termination codon $(15,43)$. The $3^{\prime}$ UTR may function to increase protein translation. Studies with ornithine decarboxylase, which is under translational control by polyamines (16), have demonstrated coordinated regulation of translation by both the 5' and 3' UTR's. Whereas ornithine decarboxylase translation initiation is inhibited by sequences in the 5' UTR of the mRNA, the $3^{\prime}$ UTR functions to augment, and partially negate, this inhibition of translation. In a recent study, the translation of rabbit erythroid 15-lipoxygenase (LOX) was shown to be inhibited by a 48-kD RNA-binding protein that bound to a region of 19 nucleotide tandem repeats on the 3' UTR of the LOX mRNA (44). The mechanism by which $3^{\prime}$ UTR protein-RNA interactions inhibit translation are not clear. In some instances, the $3^{\prime}$ UTR has been shown to be important for mRNA initiation $(13,44)$. However, since no effect on initiation was observed in these studies, some step distal to initiation, such as elongation or termination, must be involved.

In summary, regulation of LPL translation occurs in 3T3L1 cells in response to epinephrine. No structural changes in the LPL mRNA were apparent that would explain the regulation, and there was no evidence for regulation of translation initiation. Evidence for the production of a transacting protein was obtained using in vitro translation, and the loss of translational regulation occurred with the use of an LPL mRNA form that lacked the $3^{\prime}$ UTR, and by competition for transacting binding proteins with an RNA sense strand. Together, these data suggest that a transacting protein is produced in epinephrine-treated 3T3-L1 cells, and that this protein binds to the LPL mRNA between nucleotides 1599 and 1638, resulting in a decrease in translation.

\section{Acknowledgments}

We wish to acknowledge the technical assistance of Mehrnoosh Ghiam and Diane Vu. The anti-LPL antibodies were supplied by Dr. John Goers (California Polytechnic University, San Luis Obispo, CA). Construct E in Fig. 6 was a generous gift of Dr. Robert H. Eckel (University of Colorado School of Medicine).

This work was supported by National Institutes of Health grants DK 39176 and DK 26356, as well as a grant from the American Heart Association (AHA), Greater Los Angeles Affiliate. This work was also done during the tenure of an Established Investigatorship from the AHA (to P. A. Kern).

\section{References}

1. Enerbäck, S., and J. M. Gimble. 1993. Lipoprotein lipase gene expression physiological regulators at the transcriptional and post-transcriptional level. Biochim. Biophys. Acta. 1169:107-125.

2. Ong, J. M., T. G. Kirchgessner, M. C. Schotz, and P. A. Kern. 1988. Insulin increases the synthetic rate and messenger RNA level of lipoprotein lipase in isolated rat adipocytes. J. Biol. Chem. 263:12933-12938.

3. Raynolds, M. V., P. D. Awald, D. F. Gordon, A. Gutierrez-Hartmann, D. C Rule, W. M. Wood, and R. H. Eckel. 1990. Lipoprotein lipase gene expression in rat adipocytes is regulated by isoproterenol and insulin through different mechanisms. Mol. Endocrinol. 4:1416-1422.

4. Doolittle, M. H., O. Ben-Zeev, J. Elovson, D. Martin, and T. G. Kirchgessner. 1990. The response of lipoprotein lipase to feeding and fasting. Evidence for posttranslational regulation. J. Biol. Chem. 265:4570-4577.

5. Ong, J. M., and P. A. Kern. 1989. Effect of feeding and obesity on lipoprotein lipase activity, immunoreactive protein, and messenger RNA levels in human adipose tissue. J. Clin. Invest. 84:305-311. 
6. Ong, J. M., and P. A. Kern. 1989. The role of glucose and glycosylation in the regulation of lipoprotein lipase synthesis and secretion in rat adipocytes. J. Biol. Chem. 264:3177-3182.

7. Saffari, B., J. M. Ong, and P. A. Kern. 1992. Regulation of adipose tissue lipoprotein lipase gene expression by thyroid hormone in rats. J. Lipid Res. 33:241-249.

8. Ong, J. M., B. Saffari, R. B. Simsolo, and P. A. Kern. 1992. Epinephrine inhibits lipoprotein lipase gene expression in rat adipocytes through multiple steps in posttranscriptional processing. Mol. Endocrinol. 6:61-69.

9. Kozak, M. 1992. Regulation of translation in eukaryotic systems. Annu. Rev. Cell Biol. 8:197-225.

10. Klausner, R. D., and J. B. Harford. 1989. Cis-trans models for posttranscriptional gene regulation. Science (Wash. DC). 246:870-872.

11. Harford, J. B., and R. D. Klausner. 1990. Coordinate post-transcriptional regulation of ferritin and transferrin receptor expression: the role of regulated RNA-protein interaction. Enzyme (Basel). 44:28-41.

12. Munro, H. N. 1990. Iron regulation of ferritin gene expression. J. Cell. Biochem. 44:107-115.

13. Jackson, R. J., and N. Standart. 1990. Do the poly (A) tail and 3' untranslated region control mRNA translation? Cell. 62:15-24.

14. Kruys, V., M. Wathelket, P. Poupart, R. Contreras, W. Flers, J. Content, and G. Huez. 1987. The 3' untranslated region of the human interferon mRNA has an inhibitory effect on translation. Proc. Natl. Acad. Sci. USA. 89:60306034.

15. Ch'ng, J. L., D. L. Shoemaker, P. Schimmel, and E. W. Holmes. 1990 Reversal of creatine kinase translational repression by $3^{\prime}$ untranslated sequences. Science (Wash. DC). 245:1003-1006.

16. Kahana, C., and D. Nathans. 1985. Translational regulation of mammalian ornithine decarboxylase by polyamines. J. Biol. Chem. 260:15390-15393.

17. Grens, A., and I. E. Scheffler. 1990. The 5'- and 3 '-untranslated regions of ornithine decarboxylase mRNA affect the translational efficiency. J. Biol. Chem. 265:11810-11816.

18. Goers, J. F., M. E. Petersen, P. A. Kern, J. Ong, and M. C. Schotz. 1987. Enzyme-linked immunoassay for lipoprotein lipase. Ana. Biochem. 166:27-35.

19. Chomczynski, P., and N. Sacchi. 1987. Single-step method of RNA isolation by acid guanidinium thiocyanate-phenol-chloroform extraction. Anal. Biochem. 162:156-159.

20. Feinberg, A. P., and B. Vogelstein. 1983. A technique for radiolabeling DNA restriction endonuclease fragments to high specific activity. Anal. Biochem. 132:6-13.

21. Wion, K. L., T. G. Kirchgessner, A. J. Lusis, M. C. Schotz, and R. M. Lawn. 1987. Human lipoprotein lipase complementary DNA sequence. Science (Wash. DC). 235:1638-1641.

22. Gunning, P., P. Ponte, H. Okayama, J. Engel, H. Blau, and L. Kedes. 1983. Isolation and characterization of full-length cDNA clones for human a-, B-, and g-actin mRNA's; skeletal but not cytoplasmic actin have an aminoterminal cysteine that is subsequently removed. Mol. Cell Biol. 3:787-798.

23. Walden, W. E., M. M. Patino, and L. Gaffield. 1989. Purification of a specific repressor of ferritin mRNA translation from rabbit liver. J. Biol. Chem. 264:13765-13769.

24. Holm, C., T. G. Kirchgessner, K. L. Svenson, G. Fredrikson, S. Nilsson, C. G. Miller, J. E. Shively, C. Heinzmann, R. S. Sparkes, T. Mohandas, et al. 1988. Hormone-sensitive lipase: sequence, expression, and chromosomal localization to 19 cent-q13.3. Science (Wash. DC). 241:1503-1506.

25. Davis, R. C., Y. Xia, T. Mohandas, M. C. Schotz, and A. J. Lusis. 1991. Assignment of the human pancreatic colipase gene to chromosome 6p21.1 to pter. Genomics. 10:262-265.

26. Beck, E., G. Ludwig, E.-A. Auerswald, B. Reiss, and H. Schaller. 1982.
Nucleotide sequence and exact localization of the neomycin phosphotransferase gene from transposon tn5. Gene. 19:327-336.

27. Rogers, J., and H. Munro. 1987. Translation of ferritin light and heavy subunit mRNAs is regulated by intracellular chelatable iron levels in rat hepatom cells. Proc. Natl. Acad. Sci. USA. 84:2277-2281.

28. Ong, J. M., R. B. Simsolo, M. Saghizadeh, A. Pauer, and P. A. Kern 1994. The expression of lipoprotein lipase in rat muscle: regulation by feeding and hypothyroidism. J. Lipid Res. 35:1542-1551.

29. Kirchgessner, T. G., K. L. Svenson, A. J. Lusis, and M. C. Schotz. 1987 The sequence of the cDNA encoding human lipoprotein lipase: a member of a lipase gene family. J. Biol. Chem. 262:8463-8466.

30. Ranganathan, G., J. M. Ong, A. Yukht, M. Saghizadeh, R. B. Simsolo A. Pauer, and P. A. Kern. 1995. Tissue-specific regulation of human lipoprotein lipase gene expression: effect of the 3' untranslated region on translation. J. Biol. Chem. 270:7149-7155.

31. Ong, J. M., R. B. Simsolo, B. Saffari, and P. A. Kern. 1992. The regulation of lipoprotein lipase gene expression by dexamethasone in isolated rat adipocytes. Endocrinology. 130:2310-2316.

32. Fried, S. K., and R. Zechner. 1989. Cachectin/tumor necrosis factor decreases human adipose tissue lipoprotein lipase mRNA levels, synthesis, and activity. J. Lipid Res. 30:1917-1923.

33. Friedman, G., M. Ben-Naim, O. Halimi, J. Etienne, O. Stein, and Y. Stein 1991. The expression of lipoprotein lipase activity and mRNA in mesenchymal rat heart cell cultures is modulated by bFGF Biochim. Biophys. Acta. 1082:2732.

34. Previato, L., C. L. Parrott, S. Santamarina-Fojo, and H. B. Brewer, Jr. 1991. Transcriptional regulation of the human lipoprotein lipase gene in 3T3-L adipocytes. J. Biol. Chem. 266:18958-18963.

35. Simsolo, R. B., J. M. Ong, B. Saffari, and P. A. Kern. 1992. Effect of improved diabetes control on the expression of lipoprotein lipase in human adipose tissue. J. Lipid Res. 33:89-95.

36. Giralt, M., I. Martin, S. Vilaró, F. Villarroya, T. Mampel, R. Iglesias, and O. Viñas. 1990. Lipoprotein lipase mRNA expression in brown adipose tissue: translational and/or posttranslational events are involved in the modulation of enzyme activity. Biochim. Biophys. Acta. 1048:270-273.

37. Simsolo, R. B., J. M. Ong, and P. A. Kern. 1992. The characterization of lipoprotein lipase activity, secretion, and degradation at different steps of posttranslational processing in primary cultures of rat adipocytes. J. Lipid Res. 32:1777-1784.

38. Simsolo, R. B., J. M. Ong, and P. A. Kern. 1993. The regulation of adipose tissue and muscle lipoprotein lipase in runners by detraining. J. Clin. Invest. 92:2124-2130.

39. Eckel, R. H. 1987. Adipose tissue lipoprotein lipase. In Lipoprotein Lipase J. Borensztajn, editor. Evener, Chicago. 79-132.

40. Deshaies, Y., A. Géloën, A. Paulin, A. Marette, and L. J. Bukowiecki. 1993. Tissue-specific alterations in lipoprotein lipase activity in the rat after chronic infusion of isoproterenol. Horm. Metab. Res. 25:13-16

41. Davidson, N. O. 1993. Apolipoprotein B mRNA editing: a key controlling element targeting fats to proper tissue. Ann. Med. 25:539-543.

42. Sonenberg, N. 1994. mRNA translation: influence of the $5^{\prime}$ and $3^{\prime}$ untranslated regions. Curr. Opin. Genet. Dev. 4:310-315.

43. Ch'ng, J. L., R. C. Mulligan, P. Schimmel, and E. W. Holmes. 1989. Antisense RNA complementary to ${ }^{\prime}$ ' coding and noncoding sequences of creatine kinase is a potent inhibitor of translation in vivo. Proc. Natl. Acad. Sci. USA 86:10006-10010.

44. Ostareck-Lederer, A., D. H. Ostareck, N. Standart, and B. J. Thiele. 1994. Translation of 15-lipoxygenase mRNA is inhibited by a protein that binds to a repeated sequence in the $3^{\prime}$ untranslated region. EMBO (Eur. Mol. Biol. Org.) J. 13:1476-1481. 